Viso - Cadernos de estética aplicada Revista eletrônica de estética

ISSN 1981-4062

№ 9, jul-dez/2010

http://www.revistaviso.com.br/

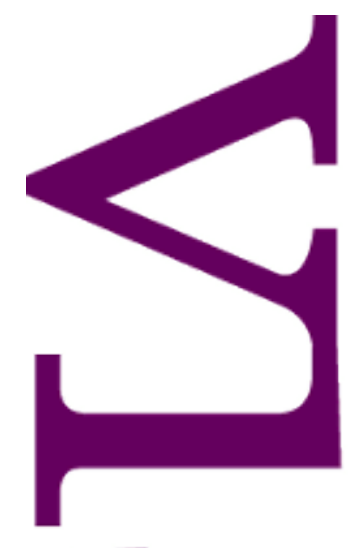

\title{
Lamento de um artista: Doutor Fausto e a Cultura Alemã Alexia Cruz Bretas
}

Universidade de São Paulo (USP) 


\section{RESUMO}

\section{Lamento de um artista: Doutor Fausto e a cultura alemã}

Este texto pretende rever a obra Doutor Fausto, de Thomas Mann, à luz de sua relação inextrincável com a história, a cultura e o pensamento alemão, aqui representado por alguns de seus maiores ícones - como é o caso de Goethe e Dürer, por exemplo. Tratase não apenas de oferecer uma leitura filosoficamente informada de um dos grandes clássicos da literatura universal, mas, sobretudo, de iluminar a via de mão dupla aberta entre as artes e a reflexão sobre elas, através do consórcio mediado entre as dimensões da literatura, da música e da estética. Para isso, a apropriação das ideias de Kierkegaard, Nietzsche e Adorno no âmago mesmo de sua forma artística desempenha um papel de suma importância em sua recepção crítica.

Palavras-chave: Doutor Fausto - Thomas Mann - cultura alemã - demoníaco - música

\section{ABSTRACT}

\section{The Lament of an Artist: Doctor Faustus and German Culture}

This text aims to review the novel Doctor Faustus, by Thomas Mann, in the light of its indissoluble relation to German history, culture and thought, here represented by some of its greatest icons - such as Goethe and Dürer. Its purpose is not only to provide a philosophically informed reading of one of the most remarkable classics of the universal literature, but also to illuminate the interface between Arts and the reflection about them, by way of a mediated interchange among Literature, Music and Aesthetics. In this sense, the appropriation of Kierkegaard's, Nietzsche's and Adorno's ideas in the own core of its artistic form plays a role of huge importance in its critical reception.

Keywords: Doctor Faustus - Thomas Mann - german culture - demoniac - music 


\section{BRETAS, A. C. "Lamento de um artista: Doutor Fausto e a cultura alemã". In: Viso: Cadernos de estética aplicada, v. IV, n. 9 (jul-dez/2010), pp. 104-122.}

DOI: 10.22409/1981-4062/v9i/104

Aprovado: 24.07.2011. Publicado: 17.08.2011.

(C) 2011 Alexia Cruz Bretas. Esse documento é distribuído nos termos da licença Creative Commons Atribuição-NãoComercial 4.0 Internacional (CC-BY-NC), que permite, exceto para fins comerciais, copiar e redistribuir o material em qualquer formato ou meio, bem como remixá-lo, transformá-lo ou criar a partir dele, desde que seja dado o devido crédito e indicada a licença sob a qual ele foi originalmente publicado.

Licença: http://creativecommons.org/licenses/by-nc/4.0/deed.pt_BR

Accepted: 24.07.2011. Published: 17.08.2011.

(C) 2011 Alexia Cruz Bretas. This document is distributed under the terms of a Creative Commons Attribution-NonCommercial 4.0 International license (CC-BY-NC) which allows, except for commercial purposes, to copy and redistribute the material in any medium or format and to remix, transform, and build upon the material, provided the original work is properly cited and states its license. License: http://creativecommons.org/licenses/by-nc/4.0/ 
Doch nur vor einem ist mir bang:

Die Zeit ist kurz, die Kunst is lang

[Só de um temor vos darei parte;

É curto o tempo, é longa a arte]

Johann Wolfgang von Goethe

Mefistófeles, em Fausto I

Publicado em 1947, Doutor Fausto [Doktor Faustus] pode ser lido como um dos mais sublimes e satânicos romances de artista [Künstlerromane] ${ }^{1}$ do século XX. Epigrafado pelo Inferno de Dante, ${ }^{2}$ este livro pungente - diabolicamente alemão - tangencia sem, contudo, deixar-se inteiramente subsumir em uma extensa linhagem de Bildungsromane ${ }^{3}$ surgida em fins do século XVIII na esteira do seminal Wilhelm Meister de Goethe. ${ }^{4}$ Figura de proa do chamado Classicismo de Weimar, o escritor, poeta e humanista é, não por coincidência, uma das influências mais importantes e duradouras na vida e obra de seu grande admirador contemporâneo, Thomas Mann. Em discurso gravado pela BBC e transmitido clandestinamente aos ouvintes alemães, em outubro de 1940, este último confirmaria tanto a inesgotável estima por Goethe, quanto a renhida aversão pelo regime nacional-socialista - que, desde 1933, forçara-o ao exílio na Suíça e, mais tarde, nos EUA.

É um escritor alemão que vos fala, um escritor que, assim como sua obra, foi proscrito pelos governantes alemães e, cujos livros, mesmo que tratem daquilo que é mais alemão, de Goethe, por exemplo, só podem falar a povos estrangeiros [...], enquanto para vocês têm de permanecer mudos e desconhecidos. ${ }^{5}$

Urdida na Califórnia, a trama de Doutor Fausto segue o fio dos acontecimentos históricos, e se constitui, retrospectivamente, a partir do entrelaçamento de três registros ou "estratos" cronológicos bem definidos, da Alemanha guilhermina ao terceiro Reich: o tempo das personagens (1885-1930), o tempo do narrador (1943-1945) e o tempo do leitor. Ao se referir aos eventos transcorridos nos anos imediatamente após o fim da primeira guerra mundial, em 1918, Mann constata:

\footnotetext{
A época que descrevo era para nós, os alemães, uma era de colapso do Estado, de capitulação, de revolta provocada pelo esgotamento, e de impotente abandono às mãos dos estrangeiros. A época na qual escrevo e que tem de me permitir deitar no papel, no meu calmo retiro, estas recordações, traz no ventre terrivelmente intumescido uma catástrofe nacional, em comparação com a qual a derrota precedente se afigura um módico infortúnio e a liquidação sensata de um empreendimento malogrado. ${ }^{6}$
}

Narrado em primeira pessoa pelo professor de filosofia Serenus Zeitblom, este grande "clássico da modernidade" registra a biografia do amigo e compositor Adrian Leverkühn, desde os anos de infância em Kaisersaschern, na Turíngia, passando pelo período de experiência escolar, teológica e musical por cidades como Leipzig, Halle e Palestrina, seguido, finalmente, de sua ascensão e queda em Pfeiffering - e daí de volta a Oberweiler onde viveria seus últimos dias. Sem sombra de dúvidas, o ponto alto da obra é o capítulo 25 - localizado, portanto, praticamente no meio do livro de 47 capítulos -, onde tem lugar o célebre "diálogo" de seu protagonista com a figura do Diabo, resultando 
no pacto que motivaria a homenagem prestada ao Fausto de Goethe ${ }^{8}$ já no título do romance - em última instância, concebido para espelhar o destino catastrófico do próprio império alemão. ${ }^{9}$

\section{Antecedentes fáusticos}

Sobre aquela obra, em particular, Hegel dirá: "Tragédia filosófica absoluta é o Fausto de Goethe, em que por um lado a insatisfação na ciência, por outro a vivacidade da vida mundana e dos prazeres terrenos, constituem uma tal amplitude de conteúdo como nenhum outro poeta dramático ousou abarcar até então numa única obra". Segundo Otto Maria Carpeaux, "o itinerário do leitor, através das páginas de Fausto, parece com a subida pelas escadas de uma torre de uma catedral gótica: é uma escada estreita e às vezes perigosa, mas no alto abre-se o panorama imenso de uma paisagem nossa: do trabalho em liberdade pela ação social e do futuro do gênero humano". Com base no Livro de Jó, ${ }^{10}$ em cenas de Hamlet e Macbeth, ${ }^{11}$ em tratados alquímico-cabalísticos, hinos sacros, canções e lendas populares, ${ }^{12}$ esta tragédia maior escrita ao longo de mais de 60 anos já foi chamada, não por acaso, de uma "obra de vida". ${ }^{13}$

Publicada pela primeira vez em 1587 pelo editor frankfurtiano Johann Spiess, a doutrinária História de $D$. Johann Fausten é usualmente apontada como a principal fonte de inspiração não somente para o Fausto de Goethe como ainda, antes dele, para The Tragical History of Life and Death of Doctor Faustus, do dramaturgo elizabetano Christopher Marlowe - peça que, anos depois, reingressaria na Alemanha como Puppenspielfabel, ${ }^{14}$ sendo assistida pelo próprio Goethe, por volta de 1768 , quando era apenas uma criança. Seja como for, além das pregnantes ressonâncias classicizantes, ${ }^{15}$ a história de Fausto seria alvo de enorme prestígio também entre os artistas românticos, sendo reconhecida e cultuada como um "bem comum da humanidade": Fausts Leben [A vida de Fausto] de Maler Müller (1778); Leben, Taten und Höllenfahrt [A vida, os feitos e a danação de Fausto] de F. M. Klinger (1791); Don Juan und Faust [Don Juan e Fausto] de Christian Dietrich Grabbe (1836); Faust. Ein Gedicht [Fausto, um poema] de Nikolaus Lenau (1836); e Doktor Faust. Ein Tanzpoem, nebst kuriosen Berichten über Teufel, Hexen und Dichtkunst [Doutor Fausto: um poema-dança acompanhado de curiosos relatos sobre o diabo, bruxas e a arte da poesia] de Heinrich Heine (1851) são apenas alguns indícios da virulenta apropriação desta trágica personagem como um dos mais ilustres heróis modernos - isso não apenas nos registros literário ou teatral, mas, de modo especialmente frutífero, também no musical, conforme as composições de Lizst, Berlioz, Schumann e Wagner deixam evidente. ${ }^{16}$

Seja como for, não obstante as irredutíveis peculiaridades que singularizam cada uma das diversas metamorfoses sofridas pelo mito fáustico, dentro e fora da Alemanha, ${ }^{17}$ todas elas atribuem à aliança com Mefistófeles o centro de gravidade em torno do qual orbitam todos os demais acontecimentos da trama. De Marlowe a Heine, passando por Lessing, Klinger e Grabbe, o acordo travado entre Fausto e o avatar de Satã capacita 
aquele primeiro a gozar, a seu bel-prazer, de riqueza material e toda sorte de satisfações mundanas durante o desenrolar de uma suntuosa e não menos trágica existência terrena - ao fim e ao cabo, tão somente humana demasiado humana. Após este prazo, Mefistófeles, em contrapartida, fará cumprir o combinado, apoderando-se de sua alma no outro mundo. Em tempo, não é supérflua aqui a ressalva: em Goethe - e, anos mais tarde, também em F. W. Murnau ${ }^{18}$-, o pacto diabólico assume a forma de uma derradeira aposta: se algum dia Fausto deixar-se entregar à indolência e à fruição hedonista, se o sábio chegar a vivenciar sequer um único momento de felicidade, de modo a desejar reter aquele belo e fugaz instante, então Mefisto, triunfante, terá vencido o desafio. "Se vier um dia em que ao momento/ Disser: Oh, para! És tão formoso!/ Então algema-me a contento,/ Então pereço venturoso!/ Repique o sino derradeiro,/ A teu serviço ponhas fim,/ Pare a hora então, caia o ponteiro,/ o Tempo acabe para mim!". ${ }^{19}$

\section{Inspiração daimônica}

Não é, pois, fortuito que o Diabo imaginado por Thomas Mann - referido apenas por "ELE" no manuscrito transcrito por Zeitblom - mantenha o tradicional intervalo de 24 anos de "enlevos", "desenfreamento", "triunfo" e "poder" antes do inexorável fim de seu interlocutor e protegé. Afinal, em Doutor Fausto, tanto quanto em seus predecessores, o tempo é, em última instância, a moeda de troca utilizada para efetivar o pacto maligno. ${ }^{20}$

Nós concedemos tempo, muitíssimo tempo, tempo em abundância, tanto tempo que nem se precisa pensar no fim. Estamos longe dele. Por ora, ninguém deve preocupar-se com o momento em que se careça dar início a tal pensamento e se possa citar: Respice finem! [Olha para o fim!]. ${ }^{21}$

Depois de trazer à luz a máxima atribuída a Bismarck de que o alemão necessita de meia garrafa de champanha para alcançar o nível normal de sua capacidade, Sammael o "Anjo da Peçonha" - anuncia a fruição de "momentos desenfreados" de um "narcisismo ébrio", o qual faria de Adrian nada menos que um soberbo "monstro divino".

Sempre que a ampulheta for acionada e o tempo tiver sido prefixado, um tempo de dimensões inimagináveis e todavia delimitado, encontramo-nos em nossos domínios e temos ricas colheitas. Vendemos tempo - digamos, vinte e quatro anos. Pode-se avistar o fim de um lapso tão grande? É adequada essa quantidade de anos? Com ela, a gente pode viver à farta, que nem os velhos imperadores, e espantar o mundo como um magnífico nigromante, através de numerosas obras diabólicas; com ela, um sujeito pode esquecer cada vez mais a lerdice e crescer, sumamente iluminado, acima de si próprio, sem, contudo, alhear-se de seu ser, não, sempre é e prossegue sendo ele mesmo; apenas ficará alçado a seu nível natural pela meia garrafa de champanha, e terá o direito de saborear, em ébrio narcisismo, todas as delícias de um quase insuportável estro, de modo que, com mais ou menos razão, chegará talvez à convicção de que, desde milênios, jamais houve tamanho engenho e simplesmente se reputará um deus em certos momentos desenfreados. Como poderá uma criatura dessas preocupar-se com o momento em que se cumpra pensar no fim? No entanto, esse fim pertence a nós; ao fim, ele será nosso. ${ }^{22}$ 
Deste modo, apesar do relativamente extenso intervalo de tempo à disposição do jovem compositor, o mais tentador da proposta luciférica diz respeito não tanto à quantidade, senão à qualidade do tempo a ele oferecido. Em última instância, o que está em jogo é a incomensurável experiência de um tempo louco, endiabrado e mesmo iluminado, cadenciado por oscilações de inspiração, folia e melancolia ${ }^{23}$ - "extremos", segundo ELE, absolutamente imprescindíveis para a manifestação de tal ingenium.

E todavia não se pode negar e nunca se negou que o elemento demoníaco, irracional, ocupa uma parcela inquietante dessa esfera luminosa, que entre ela e o reino dos Ínferos há uma ligação a despertar um leve horror e que, precisamente por isso, os epítetos positivos com os quais tentei qualificá-la, tais como 'nobre', 'humanamente sadio' e 'harmonioso', não querem adaptar-se inteiramente a ela, mesmo que [...] se trate de uma genialidade pura, autêntica, dada ou talvez infligida por Deus, e não de uma congênere adquirida, ruinosa, de consumpção pecaminosa, doentia de dons naturais, do cumprimento de um atroz contrato de compra e venda...24

Reenviando à concepção romântica do gênio criador - incorporada por autores tão díspares quanto o jovem Goethe, Hamann, Herder, Schopenhauer e Schlege ${ }^{25}$-, Thomas Mann faz de seu Mefisto o porta-voz da crença que exalta o artista como uma criatura especial ou eleita, dotada por Deus ou pela própria natureza de dons e poderes extraordinários, cujo destino não é outro que a fecundação de obras grandiosas, magníficas. Evocando as benesses de uma tal "doença criativa" ${ }^{26}$, ELE promete: "Tu serás um líder, imprimirá um ritmo à marcha que conduz ao futuro; teu nome será adorado pela juventude, que, graças à sua loucura, já não precisará enlouquecer". ${ }^{27}$

Significativamente, ao reportar-se a esta peculiar forma de loucura "produtiva", o autor recorre a termos bastante similares àqueles empregados por Nietzsche para expressar o estado de ânimo no qual ele próprio se encontrava quando the foi dado conceber seu Zaratustra. ${ }^{28}$ À medida em que tenta traduzir em palavras aquilo que os "poetas de épocas fortes" chamavam de inspiração, este último descreve:

Um pensamento reluz como relâmpago, com necessidade, sem hesitação na forma jamais tive opção. Um êxtase cuja tremenda tensão desata-se por vezes em torrente de lágrimas, no qual o passo involuntariamente ora se precipita, ora se arrasta; um completo estar fora de si, com a claríssima consciência de um sem-número de delicados tremores e calafrios que chegam aos dedos dos pés; um abismo de felicidade, onde o que é mais doloroso e sombrio não atua como contrário, mas como algo condicionado, exigido, como uma cor necessária em meio a tal profusão de luz [...]. ${ }^{29}$

Em seu afã de reconstituir as centelhas poéticas auferidas pelo "pathos trágico" que então o possuía no mais alto grau, Nietzsche explicita que tudo se passa de modo totalmente involuntário, como numa espécie de "turbilhão" movido pela sensação de liberdade, de incondicionalidade, de poder, de divindade. $\mathrm{O}$ autor ainda destaca o caráter irredutivelmente singular e intempestivo de sua experiência daimônica, e prognostica: "Esta é a minha experiência da inspiração; não duvido que seja preciso retroceder milênios para encontrar alguém que me possa dizer: 'é também a minha'”. ${ }^{30}$ 
Seguindo de perto o registro nietzschiano, Mann, por seu turno, não hesita em apropriarse da descrição do filósofo - tanto quanto Leverkühn periodicamente acometido por surtos de "êxtase e entusiasmo" ao que tudo indica decorrentes da evolução da sífilis para ressaltar o caráter, no limite, "patológico" destes momentos de mania ou furor criativo como propedêutica para a irrupção de obras sublimes.

Uma inspiração deveras deleitosa, fascinante, indubitável, férvida; uma inspiração na qual não há nem escolha nem correção nem remendos e na qual se acolhe tudo como um benfazejo ditado; uma inspiração que faz com que o passo estaque e tropece, com que sublimes tremores percorram da cabeça aos pés o ente agraciado e lhe arranquem dos olhos uma torrente de lágrimas de felicidade - não, tal inspiração não é possível com Deus, que abandona demasiado trabalho ao intelecto. É possível unicamente com o Diabo, o verdadeiro senhor do entusiasmo. ${ }^{31}$

Com Nietzsche, Mann ainda sustenta que aquilo que, na era clássica, talvez se pudesse obter sem a intervenção demoníaca, atualmente só ELE pode proporcionar: o "autêntico", o "primordial", o "arcaico", o que desde tempos imemoriais ninguém ousou experimentar novamente, a saber, o velho "transe sagrado" não deteriorado nem pela crítica negativa, nem pelo mortífero controle intelectual.

Donde resulta que ao investir a esfera da criação artística de uma imediaticidade, em larga medida, refratária aos protocolos da reflexão estética, o autor vai ao encontro da noção kierkegaardiana que compreende o elemento demoníaco como intrinsecamente musical - e vice-versa. Não é, portanto, por mera casualidade que exatamente entre as páginas do livro que Adrian Leverkühn estava lendo momentos antes da repentina aparição do Diabo esteja escrito: "A música é o demoníaco". ${ }^{32}$ Com base em sua singular apreciação do Don Giovanni de Mozart, Kierkegaard lança a hipótese segundo a qual a figura de Don Juan corresponderia à expressão sensual do demoníaco - Fausto, por seu turno, representaria sua contraparte "espiritual". ${ }^{33}$ Já em Thomas Mann, a relação de família entre a música e a figura do Diabo é atestada pela engenhosa argumentação deste último, que garante:

Acho que o Diabo deve entender-se de Música. Se não me engano, lias há pouco um
livro daquele cristão apaixonado pela Estética. Ele, sim, estava a par do assunto e
conhecia muito bem minha relação com essa linda arte - a mais cristã de todas, na
opinião dele - porém, julgava-a de modo negativo, como uma arte instituída e
desenvolvida pelo cristianismo, mas rejeitada e proscrita por pertencer ao feudo do
Demônio. Estás vendo? A Música é uma matéria altamente teológica, da mesma forma
que o pecado, da mesma forma que eu. ${ }^{34}$

\section{A nova música}

Contudo, pela via teológica, o "daimon particular" de Adrian Leverkühn despede-se, em definitivo, do romantismo cristão de Sören Kierkegaard para seguir as trilhas abertas pela vitalista musicalidade de Friedrich Nietzsche ${ }^{35}$ Ao referir-se a uma de suas obras mais efusivamente visionárias, o amigo, admirador e crítico aguerrido de Richard Wagner ${ }^{36}$ 
compara: "Talvez se possa ver o Zaratustra inteiro como música; - certamente um renascimento da arte de ouvir era uma precondição para ele". ${ }^{37}$ Segundo as palavras do próprio filósofo, seu conceito de "dionisíaco" teria nesta obra se convertido em "ato supremo". Ao investir Zaratustra das qualidades "sobre-humanas" do Übermensch, ele garante que nem Goethe, nem Shakespeare seriam capazes de respirar sequer um instante nessa paixão e altura tremendas - comparativamente, o próprio Dante seria apenas "um crente". Ainda segundo o autor, nunca houve "sabedoria", "pesquisa da alma" ou "discurso" antes de Zaratustra: o mais prosaico, o mais imediato falaria "coisas inauditas" ali. "A sentença fremente de paixão; a eloqüência tornada música; raios arremessados adiante, a futuros ainda insuspeitos. A mais poderosa energia para 0 símbolo até aqui existente é pobre brincadeira, frente ao retorno da linguagem à natureza mesma da imagem". ${ }^{38}$ Apropriando-se dos cantos de louvor originalmente entoados para homenagear o deus Dionísio nas tragédias áticas, o filósofo indaga: "Que linguagem falará um tal espírito, ao falar só consigo mesmo? A linguagem do ditirambo. Eu sou o inventor do ditirambo". ${ }^{39}$

Porém, a despeito das inúmeras "afinidades eletivas", ${ }^{40}$ a fecunda influência nietzschiana vai somente até certo ponto nesta complexa e multifacetada obra de maturidade de Thomas Mann - não por acaso, concebida sob os auspícios da técnica da montagem. ${ }^{41}$ Para compreender seus limites e potencialidades, o aporte das ideias de Adorno revelase crucial para um adequado entendimento do erudito debate estético que permeia grande parte do romance, cujo núcleo teórico-argumentativo gira em torno das dificuldades enfrentadas pelos compositores da nova música - entre os quais Schoenberg ocupa um lugar decerto preponderante.

A propósito, em $A$ gênese do Doutor Fausto, Mann protocola suas primeiras impressões sobre a benfazeja "descoberta" dos textos adornianos - dois dos quais, em particular, tratam justamente das questões musicais analisadas pelo viés hegeliano-marxista de uma dialética da razão: "O fetichismo na música e a regressão da audição" (1938) e "Filosofia da nova música" (1941). O escritor constata: "Encontrei um crítico artístico e sociológico de nossa situação atual da mais sutil, progressiva e profunda espécie, que demonstra uma tocante afinidade com a concepção central do meu próprio trabalho, no qual estava então envolvido". ${ }^{42}$ Seu depoimento confirma o surgimento de um profícuo relacionamento social e intelectual entre ele e Adorno - ambos, nesta época, radicados nos EUA. Por sinal, a correspondência de 1943 a 1955 trocada pelos dois autores então exilados na Califórnia constitui um importante documento histórico, no qual são esboçados os traços - certamente ainda vacilantes - de um possível "projeto" em comum, qual seja, a configuração de uma forma concreta de pensamento, capaz de conciliar dialeticamente os momentos conceitual e intuitivo da experiência artística pelo recurso às mediações da imaginação produtiva.

Fato é que o contato com o ensaio de Adorno sobre Schoenberg ${ }^{43}$ viria a estimular intrincadas discussões não apenas sobre a articulação geral de Doutor Fausto, quanto 
ainda sobre detalhes teóricos bastante específicos a respeito do estado da arte da composição musical - conforme se pode notar, por exemplo, no vigésimo segundo capítulo do romance, onde são lançadas e discutidas algumas proposições extraídas da Harmonielehre [Teoria da Harmonia] de Schoenberg. ${ }^{44} \mathrm{Na}$ medida em que realiza a distinção entre épocas de "culto" e de "cultura", Mann atribui a Adrian o pensamento de que a separação da arte do âmbito litúrgico teria significado uma importante conquista para a liberdade e a autonomia dos artistas - os quais, no entanto, tenderiam a padecer das mazelas de uma insuperável sensação de "solidão pessoal" crivada pelos estigmas do "sofrimento patético" e da "gravidade absoluta" - marcas registradas dos românticos alemães. Em seguida, ao refletir sobre o caráter histórico e, portanto, necessariamente transitório da própria noção de cultura, Leverkühn revida nestes termos à provocação do jovem conservador Serenus Zeitblom - para quem "cultura" e "barbárie" seriam noções não apenas antitéticas, como mutuamente exclusivas: "A barbárie é o oposto da Cultura somente naquela ordem de pensamentos que esta coloca à nossa disposição. Fora de tal ordem, o oposto pode ser muito diferente e talvez nem seja oposto". ${ }^{45}$

Ressoando a divisa benjaminiana que afirma que todo monumento da cultura é também um documento da barbárie $(1940)^{46} \mathrm{e}$, em parte, também o Leitmotiv da Dialektik der Auflärung (1946) - "o mito já é esclarecimento, e o esclarecimento acaba por reverter à mitologia"47 -, Thomas Mann retoma o debate "civilização" [Zivilisation] versus "cultura" [Kultur] em outra chave. Aqui não se trata de contrapor a herança essencialmente cosmopolita e democrática defendida pelos franceses à tradição germânica assentada em valores aristocráticos e pulsões arcaicas, mas, em vez disso, de mostrar a terrível imbricação entre os aspectos progressivos e regressivos da cultura em um mesmo constructo de dominação. Não é, pois, acidental que Lúcifer - travestido de intelectual musicólogo à la Adorno - proponha a Adrian: "A fase da Cultura e de seu culto serão superadas por ti; terás a audácia de uma barbárie duplamente bárbara”. ${ }^{48}$ Segundo ELE, quinhentos anos após a cultura renegar sua dimensão religiosa - pondo-se, em contrapartida, a "cultuar-se a si mesma" - todos estariam tão fartos e cansados dela "como se tivessem engolido panelas cheias de comida". Diante deste estado generalizado de mal-estar ou "indigestão", surge a necessidade imperativa de se romper com os padrões consagrados pela "Cultura oficial" em prol da criação de formas autênticas, condizentes com uma nova subjetividade em processo de "fermentação".

Nesse ponto, as inquietações mefistofélicas compartilhadas por Leverkühn alinham-se com o grito de protesto das vanguardas artísticas, resultando no ímpeto de renovação que, no plano do modernismo musical, daria origem a duas tendências ou vetores "extremos". ${ }^{49}$ De um lado, a corrente "restauradora" do movimento representado por Igor Stravinski - o qual, a exemplo da fenomenologia husserliana, opta por renunciar a todo psicologismo vulgar em nome de um contato direto com a matéria-prima da música, promovendo, de um só golpe, a regressão ao arcaico e a involução da linguagem musical; de outro lado, a corrente "progressiva" capitaneada por Arnold Schoenberg - o compositor e teórico radical que, inspirado pela expressão de origem wagneriana, 
desenvolveria seus próprios conceitos e técnicas no plano da objetividade musical, celebrizando-se como o autor de uma das principais inovações na história da música do século XX: o dodecafonismo. ${ }^{50}$ Ainda de acordo com Adorno, ambas as correntes configurariam, juntas - em irredutível tensão dialética - o complexo campo de forças ao qual o compositor da nova música estaria impreterivelmente sujeito ao buscar soluções para os impasses - não apenas técnicos - de seu inadiável ofício.

Entretanto, já no prefácio de sua Filosofia da nova música, o filósofo verbaliza um pensamento bastante incômodo, que, talvez, possa aqui ser livremente atribuído também ao autor de Doutor Fausto ao dedicar volumosas páginas de seu "romance de artista" [Künstlerroman] a discussões um tanto áridas sobre os atuais desafios da composição musical e suas aporias.

Parece realmente cínico que, depois do que ocorreu na Europa e o que ainda ameaça ocorrer, dedique tempo e energia intelectual a decifrar os problemas esotéricos da moderna técnica da composição; além disso, as obstinadas discussões do texto, puramente formais, com frequência referem-se diretamente a uma realidade que não se interessa por elas. ${ }^{51}$

Mantendo uma distância crítica de posicionamentos extremos como o romantismo utópico de Ernst Bloch ou o engajamento político de Bertolt Brecht, Adorno, contra Lukács, defende a autonomia da forma como dispositivo de segurança contra os abusos, quer da "estetização da política" ou da "politização da arte". ${ }^{22}$ Contra a instrumentalização das obras pelos protocolos da militância marxista, o autor contesta: "A crua atribuição da música a classes e grupos é meramente assertiva e se converte muito facilmente no mau gosto da perseguição ao formalismo com o qual se estigmatiza como decadência burguesa tudo aquilo que não se abstém de fazer o jogo da sociedade existente". ${ }^{53}$ Para ele, "a obra de arte dá uma resposta à heteronomia da sociedade com tão maior exatidão quanto mais está perdida para o mundo". ${ }^{54}$ Por isso, os alegados traços de "hermetismo" e/ou "intelectualismo", não raro atribuídos às composições modernistas, convertem-se nos últimos bastiões de sua deliberada recusa em acatar como dada a ignóbil cooptação seja do "harmônico classicismo vienense" ou da "transbordante nostalgia romântica" como anódinos artigos de consumo das massas. Daí, segundo o filósofo e admirador de Schoenberg, toda a beleza da arte contemporânea consistir precisamente em subtrair-se à enganadora aparência do belo.

Aqui, ratificando, com Adorno, que "a situação é demasiado crítica para que a ausência de crítica esteja à altura", ${ }^{55}$ é Thomas Mann - na figura do "Grão-tinhoso" - quem assevera:

Esta já não suporta a aparência e o jogo, a ficção, a autocracia da forma, que censura as paixões e o sofrimento humano, distribui os papéis e os converte em quadros. Admissível resta a expressão da dor em seu momento real, expressão não fictícia, não brincalhona, não dissimulada, não transfigurada. A impotência e a miséria cresceram a tal ponto que não é mais permitido realizar com elas jogos imaginários. ${ }^{56}$ 
Cônscio da insolúvel extemporaneidade de tal imperativo estético, Adorno, contudo, pondera: "a esta experiência tende espontaneamente a música nova, experiência que a música mecânica realiza permanentemente: a experiência do esquecimento absoluto. É verdadeiramente uma mensagem encerrada numa garrafa". ${ }^{57}$

\section{Crepúsculo da humanidade}

Ora, se em Doutor Fausto a destruição de Adrian Leverkühn foi originalmente pensada como símile da desintegração do próprio Reich, a interlocução entre Mann e Adorno imprime uma notável virada na constituição de seu protagonista. Isso porque a imagem do artista de vanguarda - movido pela embriaguez dionisíaca e inflamado por eflúvios românticos - deixa de aplicar-se inteiramente a Adrian - "demasiado pudico, frio e casto para o elementar". Deste modo, sua "frieza" natural - ressaltada pelas semelhanças com o filósofo frankfurtiano - tende a bloquear ou, ao menos em parte, interromper a dinâmica de identificação imediata entre sua irredutivelmente fleumática personalidade e a convulsiva juventude alemã à mercê dos mais descontrolados excessos. Esta peculiar tendência à incorrigível ausência de ardor é, por sinal, acentuada por uma cláusula especial do interdito demoníaco, que proíbe textualmente: "Queremos que fiques tão frio, que nem sequer as chamas da produção criativa sejam bastante quentes para te aquecerem". ${ }^{58} \mathrm{E}$ mais: "O amor te fica proibido, porque esquenta. Tua vida deve ser frígida, e, portanto, não tem o direito de amar". ${ }^{59}$ Não por acaso, a alusão à fábula da "Pequena Sereia" é constante em todo o livro. ${ }^{60}$ Tanto quanto a desafortunada personagem deste melancólico conto de Andersen, Adrian constrói a autoimagem de um ser permanentemente afligido por dores excruciantes provenientes de uma existência híbrida - meio homem, meio criatura de "sangue frio" -, cujos tormentos revelam-se indissociáveis desta terrível condição "inumana", "desumana" ou mesmo, "sobrehumana". Entretanto, renunciar a esta "frigidez" constitutiva e deixar-se "esquentar" pelo sentimento amoroso representaria uma grave transgressão ao pacto demoníaco, vindo a precipitar não apenas a própria ruína, como também a fatal aniquilação do objeto de tais emoções "calorosas" e desastrosas em partes iguais - aliás, é precisamente o que ocorre ao amigo Rudi Schwerdtfeger e ao pequeno Nepomuk.

Assim é que privado de um contato plenamente afetivo com o mundo circundante, Leverkühn escolhe para si uma espécie de refúgio incrustado na região rural da Alta Bavária - a propósito, bastante aparentada com a pacata granja de Buchel onde passara a infância -, lá construindo um prosaico e até ascético universo particular, estruturado de modo a dedicar-se de corpo e alma ao obstinado desempenho das atividades artísticas. Como resultado de uma intensa e fulgurante produção musical, são dignas de nota, em especial, duas obras magnas de sua autoria, ambas concebidas sob os auspícios do pacto mefistofélico: Apocalipsis cum figuris (1919-1926) e Dr. Fausti Wehlag [Lamento do Dr. Fausto] (1927-1930). Analisadas em retrospecto, elas engendram uma constelação infernal bastante peculiar, cuja intrincada composição revela-se indissociável das mazelas que, no plano social e político, sucedem-se à fragorosa derrota alemã na 
primeira guerra mundial, prenunciando catástrofes ainda maiores com a dissolução da República de Weimar e a tomada do poder pelos nacional-socialistas. Portanto, a julgar pelas correspondências historiográficas, pode-se traçar uma linha de relativa continuidade entre o "oratório apocalíptico" inspirado nas revelações de São João ilustradas por Dürer e a cantata "de infinita tristeza" na qual a expressão assume, derradeiramente, a forma do lamento.

Ao comentar a "formidável plasticidade" do Apocalipsis cum figuris, Mann evoca tanto o "espaço repleto de pormenores fantasticamente exatos" de Dürer, quanto o monumental afresco do Juízo Final de Michelangelo, chamando atenção para as semelhanças deste "quadro sonoro de Leverkühn" ${ }^{11} \mathrm{com}$ as profecias de Ezequiel, ${ }^{62}$ bem como com o infernal périplo dantesco.

Tudo isso contribui para que se crie a impressão geral de um outro mundo que se abre e de uma prestação de contas que se inicia, de uma viagem ao Inferno, na qual se inserem e amalgamam visionariamente as representações do Além de fases primitivas, xamanísticas, da Antiguidade e do cristianismo até a época de Dante. ${ }^{63}$

Longe de recorrer às figuras da redenção entronizadas pela música romântica, Adrian Leverkühn enfatiza o caráter "teologicamente negativo" de seu drama musical, dando a Zeitblom a impressão de ouvir os sons produzidos por "uma queda sem esperança num escancarado abismo". ${ }^{64}$ Não por acaso, a imagem dos quatro cavaleiros do Apocalipse é evocada para expressar o cenário de ruína e devastação - interna e externa - causado pela malfadada campanha belicista de Guilherme II - de cujo entusiasmo inicial muitos de seus adeptos, anos mais tarde, se arrependeriam, relembrando, com pesar, o pathos guerreiro encampado por uma "alma poderosamente trágica" aniquilada pelo amor outrora consagrado "a qualquer destino, seja ele o que for, ainda que nos traga o ocaso que abrase o céu com o rubor de um crepúsculo dos deuses". ${ }^{65}$

Era isso o que o 'Destino' - que palavra alemã, com seu som primevo, pré-cristão, motivo trágico mitológico, de drama musical! - era, pois, isso que o 'Destino' resolvera e a cuja realização nós nos encaminhávamos, entusiasmados (num entusiasmo que ninguém partilhava conosco). Estávamos persuadidos que a hora secular da Alemanha acabava de soar, que a História mantinha acima de nós suas mãos protetoras, que, após a Espanha, a França, a Inglaterra, chegara a nossa vez de imprimirmos nosso cunho ao mundo e de sermos seus governantes. Tínhamos a convicção firme de que o século $X X$ pertencia a nós e que, depois de uma era burguesa inaugurada uns cento e vinte anos atrás, o mundo devia renovar-se sob o signo germânico, signo de um socialismo militarista ainda não claramente definido. ${ }^{66}$

Contudo, sob a implacável égide da "renovação", a trágica hybris germânica precipitou nada menos que a profética consumação das mais atrozes imagens poéticas do "fim do mundo", por sinal, compiladas na célebre antologia expressionista Menschheitsdämmerung ${ }^{67}$ - fatídico crepúsculo de uma humanidade agônica, sem perspectiva de aurora mitigante ou catarse reconciliadora. 
Tudo se arremessa, precipita-se em direção ao fim. Sob o signo do fim se encontra o globo, pelo menos para nós, os alemães, cuja história milenar ficou refutada, levada ad absurdum, baldada tragicamente, e se evidencia errada, como demonstra esse seu resultado. Ela embocará no nada, no desespero, em bancarrota sem igual, na descida ao Inferno em meio a chamas estrondeantes, que bailam ao redor. ${ }^{68}$

Ao comentar o significado do pacto demoníaco para a vida e a obra de Adrian Leverkühn em paralelo com o destino da própria Alemanha imperial, Rüdiger Safranski sintetiza:

Ambos fazem um pacto com o demônio para alcançar novamente as fontes de energia viva: a Alemanha, para achar o caminho de uma sociedade desintegrada para uma comunidade com sentimentos fortes; Leverkühn, para experimentar a embriaguez criativa e a libertação dionisíaca e para abrir caminho, desde o excesso de reflexão até o sentimento elementar, para uma segunda ingenuidade. A Alemanha busca a revolução vital; Leverkühn, a inspiração. No fim, ambos são carregados pelo demônio. ${ }^{69}$

A título de epílogo, são bastante expressivas as últimas palavras de Doutor Fausto, as quais, sob a perspectiva romântico-desencantada ${ }^{70}$ de seu narrador, evocam a imagem de Adrian Leverkühn como a derradeira encarnação da juventude alemã subjugada pelos desdobramentos de um sinistro pacto satânico - selado com sangue e saldado catastroficamente.

A essa altura, a Alemanha, as faces ardentes de febre, no apogeu de selvagens triunfos, cambaleava, ébria, a ponto de conquistar o mundo, graças a um pacto ao qual tencionava manter-se fiel e que assinara com seu sangue. Hoje, cai de desespero em desespero, cingida de demônios, cobrindo um dos olhos com a mão e cravando o outro num quadro horroroso. Quando alcançará o fundo do abismo? Quando raiará, em meio à derradeira desolação, um milagre superior a qualquer fé, a luz da esperança? Um homem solitário junta as mãos e diz: 'Que Deus tenha misericórdia de vossas pobres almas, meu amigo, minha pátria!'71

Triste e pungente lamento sem redenção - acerto de contas de um artista, de uma época, de uma nação.

\section{* Alexia Cruz Bretas é doutora em filosofia pela USP.}

${ }^{1}$ Ver MARCUSE, H. Der deutsche Künstlerroman. In: Schriften, vol. 1. Springe: Zu Klampen, 2004.

${ }^{2}$ ALIGHIERI, D. A divina comédia. Inferno. Tradução de Italo Eugenio Mauro. São Paulo: Ed. 34, 1998.

${ }^{3}$ Literalmente, romances de educação ou formação. Sobre as dificuldades inerentes à tradução do termo alemão Bildung, ver MAZZARI, M. V. "Apresentação". In: GOETHE, J. W. Os anos de aprendizado de Wilhelm Meister, Tradução de Nicolino Simone Neto. São Paulo: Ed. 34, 2006, p. 11. Sobre a definição do Bildungsroman, ver HEGEL, F. Vorlesungen über die Ästhetik, Bänden 1315. Frankfurt a.M.: Suhrkamp, 2007. Edição brasileira: HEGEL, F. Cursos de estética, vols. 1-3. São Paulo: EDUSP, 2000; JACOBS, J. Wilhelm Meister und seine Brüder. Untersuchungen zum deutschen Bildungsroman. Munique: Wilhelm Fink, 1972; SELBMANN, R. Der deutsche Bildungsroman. Stuttgart: Metzler, 1984; e MAZZARI, M. V. Romance de formação em perspectiva histórica. São Paulo: Ateliê, 1999. 
${ }^{4}$ Ver GOETHE, J. W. Wilhelm Meisters Lehrjahre. Leipzig: Reclam, 2008. Edição brasileira: GOETHE, J. W. Os anos de aprendizado de Wilhelm Meister, op. cit. Sobre Wilhelm Meister, Lukács dirá que "[...] seu tema é a reconciliação do indivíduo problemático, guiado pelo ideal vivenciado, com a realidade social concreta". Teoria do romance. São Paulo: Ed. 34, 2000, p. 138. Contudo, apesar das ressonâncias, em Doutor Fausto não subsiste qualquer possibilidade de reconciliação harmônica entre a subjetividade do artista e a objetividade do mundo circundante. Razão pela qual esta obra demoníaca não pode, rigorosamente, ser tomada como um legítimo romance de educação ou de formação [Bildungsroman] no sentido estrito do termo. A esse respeito, ver, MAZZARI, M. V. Labirintos da aprendizagem: pacto fáustico, romance de formação e outros temas de literatura comparada. São Paulo: Ed. 34, 2010.

${ }^{5}$ MANN, T. Ouvintes alemães! Discursos contra Hitler (1940-1945). Tradução de Antonio Carlos dos Santos e Renato Zwick. Rio de Janeiro: Zahar, 2009.

${ }^{6}$ Idem. Doutor Fausto. Tradução de Herbert Caro. Rio de Janeiro: Nova Fronteira, 2000, p. 471.

${ }^{7}$ Ver HEISE, Eloá. "Thomas Mann: um clássico da modernidade”. Revista Letras, Curitiba, n. 39, pp. 239-246, 1990.

${ }^{8}$ GOETHE, J. W. von. Fausto: uma tragédia (primeira parte). Tradução: de Jenny Klabin Segall. São Paulo: Ed. 34, 2004. Sobre a tragédia goethiana, vale conferir o volumoso tomo de JAEGER, M. Faustus Kolonie. Goethes kristische Phänomenologie der Moderne. Würzburg: Königshausen \& Neumann, 2005; o volume de SCHMIDT, J. Goethes Faust. Erster und Zweiter Teil. Grundlagen. Werk. Wirklung, 2001; bem como a autobiográfica abordagem de NEGT, O. Die Faust-Karriere: vom verzweifelten Intellektuellen zum gescheiterten Unternehmer, 2006; além de BARRENTO, J. (org.). Fausto na literatura europeia. Lisboa: Apaginastantas, 1984; CAMPOS, H. Deus e o diabo no Fausto de Goethe. São Paulo: Perspectiva, 1981; e HEISE, E. "Fausto: a busca pelo absoluto". In: Cult, n. 130, 24/03/2010. Disponível em: <http://revistacult.uol.com.br/home/2010/03/fausto-abusca-pelo-absoluto/>. Acesso em: 02/11/2010.

${ }^{9}$ A esse respeito, ver SAFRANSKI, R. "A catástrofe e sua interpretação romântica: o Doutor Fausto de Thomas Mann”. In: Romantismo: uma questão alemã. São Paulo: Estação Liberdade, 2010.

${ }^{10}$ Conforme as sagradas escrituras: "Perguntou o Senhor a Satanás: 'Observaste a meu servo Jó? Porque ninguém há na terra semelhante a ele, homem íntegro e reto, temente a Deus, e que se desvia do mal'. Então respondeu Satanás ao Senhor: 'Por ventura, Jó teme em vão a Deus? Acaso não o cercaste com sebe, a ele, a sua casa e a tudo quanto tem? A obra de suas mãos abençoaste, e os seus bens se multiplicaram na terra. Estende, porém a tua mão, e toca-lhe em tudo quanto tem, e verá se não blasfema contra ti na tua face!' Disse o senhor a Satanás: 'Eis que tudo quanto ele tem está em teu poder; somente contra ele não estendas a mão. E Satanás saiu da presença do Senhor'”. Jó 1.8-12.

${ }^{11}$ Pelo que consta, Byron teria acusado Goethe de plagiar Shakespeare na canção de amor da jovem Ofélia. Com respeito às apropriações artísticas, o escritor alemão sustenta em conversa com o secretário: "Não pertence tudo o que se fez, desde a Antiguidade até o mundo contemporâneo, de jure, ao poeta? Porque ele haveria de hesitar em colher flores onde as encontrasse? Somente se pode produzir algo grande mediante a apropriação dos tesouros alheios. Eu não me apropriei de Jó para Mefistófeles e da canção de Shakespeare?" GOETHE, J. W. apud CAMPOS, H. Deus e o diabo no Fausto de Goethe, op. cit., p. 76.

12 De acordo com relatos orais, as origens da personagem "Fausto" remontam a um certo erudito Georgius ou Johann que teria supostamente vivido na Alemanha entre os anos de 1470 e 1540.

${ }^{13}$ Sobre a gênese do Fausto goethiano, ver MAZZARI, M. V. "Goethe e a história do Doutor Fausto: do teatro de marionetes à literatura universal". In: GOETHE, J. W. von. Fausto: uma tragédia (primeira parte), op. cit., pp. 12-16.

${ }^{14}$ Espetáculo de marionetes. 
${ }^{15}$ Vale dizer que a despeito da enorme repercussão da história de Fausto junto ao grande público, seu êxito não se restringiria apenas às camadas populares. Também no meio erudito, a tragédia do sábio instigado pelo "demo" deixaria importantes vestígios, como é o caso do fragmento dramático Faust de G. E. Lessing - publicado em 1759, numa reação contra a hegemonia do classicismo francês nos palcos germânicos.

${ }^{16}$ Não obstante as declarações do próprio Goethe de que somente Mozart poderia conceber a música de Fausto, inúmeros outros compositores deixaram-se inspirar pela estória do sábio que negocia sua alma com o Diabo. É o caso do húngaro Franz Liszt, autor da sinfonia em três movimentos composta para a inauguração oficial do célebre monumento de Goethe e Schiller na praça do teatro em Weimar (Faust-Symphonie, 1857). Além desta peça, vale destaque para outras quatro óperas espetacularmente encenadas como drama musical: as sete canções para a primeira parte do Fausto de Goethe compostas por Richard Wagner (Faust, 1831); a versão de Hector Berlioz com libreto de Gerardo Gandonniere (La Damnation de Faust, 1846); a Magum Opus de Robert Schumann (Szenen aus Goethes Faust, 1844-1853); e finalmente a ópera de Charles Gounod com libreto de Jules Barbier e Michel Carré (Faust, 1859).

17 Também fora da Alemanha, a história de Fausto inspiraria obras de artistas tão heterogêneos quanto o russo Alexander Púchkin (Faust, 1926); o francês Paul Valéry (Mon Faust, 1946) e o português Fernando Pessoa (Fausto: tragédia subjetiva. Lisboa: Presença, 1988).

${ }^{18}$ Ver Fausto. Direção de F. W. Murnau. 1 DVD, 144 minutos, P\&B, Continental, 2004.

${ }^{19}$ Do original, em alemão, "Werd'ich zum Augenblick sagen:/ Verweile doch! du bist so schön!/ Dann magst Du mich in Fesseln schlagen,/ Dann will ich gern zugrunde gehn!/ Dann mag die Totenglocke schallen,/ Dann bist du deines Dienstes frei,/ Die Uhr mag stehn, der Zeiger fallen,/ Es sei die Zeit für mich vorbei”. Ibidem, pp. 168-169.

${ }^{20}$ Aliás, como também na História do diabo, de Vilém Flusser, o demoníaco é configurado como o avatar do próprio tempo. FLUSSER, V. A história do diabo. São Paulo: Annablume, 2005.

${ }^{21}$ MANN, T. Doutor Fausto, op. cit., p. 323.

22 Ibidem, p. 324.

${ }^{23}$ Sobre a constelação gênio-loucura-melancolia, ver CLAIR, J. "Eine faustische Melancholie", in: CLAIR, J. (org.). Melancholie: Genie und Wahnsinn in der Kunst. Paris; Ostfildern: Gallimard; Hatje Cantz, 2005, pp. 452-461. Vale atentar para o fascínio de Adrian Leverkühn pelo símbolo do "quadrado mágico" presente na xilogravura Melancolia I de Albrecht Dürer. Aparecendo em destaque numa ilustração que o jovem mantém afixada em seu quarto de estudo em Halle e depois em Leipzig, o mesmo desempenhará um papel crucial em suas composições musicais sobretudo, no Apocalipsis cum figuris, não por acaso, título de um livro de Dürer. Zeitblom observa: "Acima, na parede, achava-se fixada com percevejos uma gravura aritmética, espécie de quadrado mágico, assim como se vê também na Melancolia de Dürer, ao lado da ampulheta, da balança, do poliedro e de outros símbolos. Como lá, a figura estava subdividida em dezesseis campos numerados com algarismos árabes, de tal modo que o 1 se encontrava no campo inferior à direita e o 16 no superior à esquerda; a magia, ou a curiosidade, consistia na circunstância de que as cifras, indiferente de que maneira fossem somadas, de cima para baixo, de um lado para outro ou na diagonal, sempre davam o total de 34". MANN, T. Doutor Fausto, op. cit., pp. 131-132. Para duas notáveis leituras da Melancolia I de Dürer, ver PANOFSKY, E. A evolução da idéia de belo. São Paulo: Martins Fontes, 1994; e BENJAMIN, W. Origem do drama barroco alemão. Tradução: Sérgio Paulo Rouanet. São Paulo: Brasiliense, 1984.

${ }^{24}$ MANN, T. Doutor Fausto, op. cit., p. 11.

${ }^{25}$ Ver SUZUKI, M. O gênio romântico. São Paulo: lluminuras, 2000.

${ }^{26}$ Com base em sua amizade por Adrian Leverkühn, Serenus Zeitblom, com Nietzsche, constata: "o gênio é uma forma de energia vital, profundamente conhecedora da doença, abeberada na mesma e criativa através dela". MANN, T. Doutor Fausto, op. cit., p. 497. 
${ }^{27}$ Ibidem, p. 342.

${ }^{28}$ Sobre a influência dos autores românticos na estética nietzschiana, ver ARALDI, C. L. "O gênio romântico no pensamento de Nietzsche". In: Artefilosofia, n. 6, Ouro Preto, 2009, pp. 183-193.

${ }^{29}$ NIETZSCHE, F. Ecce homo. Como alguém se torna o que é. São Paulo: Companhia de bolso, 2009 , p. 82.

${ }^{30}$ Ibidem, p. 83.

${ }^{31}$ MANN, T. Doutor Fausto, op. cit., p. 335.

${ }^{32}$ KIERKEGAARD, S. "The immediate erotic stages or the musical erotic". In: Either/Or: a fragment of life. London: Penguin, 1992, p. 83.

${ }^{33}$ A esse respeito, ver GRAMMONT, G. Don Juan, Fausto e o judeu errante em Kierkegaard. Petrópolis: Catedral das Letras, 2003.

${ }^{34}$ MANN, T. Doutor Fausto, op. cit., p. 341.

35 Sobre a característica intrinsecamente musical do pensamento nietzschiano, vale conferir BARROS, F. M. O pensamento musical de Nietzsche. São Paulo: Perspectiva, 2007.

${ }^{36}$ A esse respeito, ver NIETZSCHE, F. O caso Wagner: um problema para músicos. São Paulo: Companhia das Letras, 1999; e . "O caso Wagner: um problema para músicos". In: Ecce hommo, op. cit., pp. 96-101.

${ }^{37}$ NIETZSCHE, F. Ecce homo, op. cit., p. 79. Escrito entre agosto de 1881 e fevereiro de 1883, Assim falava Zaratustra [Also sprach Zarathustra] traz como concepção fundamental a ideia do eterno retorno. Lançado como a "mais elevada forma de afirmação" que se pode alcançar, tal pensamento, segundo Nietzsche, teria sido prenunciado pelo voo da "fênix Música", a qual, ainda na primavera, passara sobre ele e o maestro Peter Gast "com plumagem mais leve e luminosa do que jamais exibira". Outro indício que parece confirmar a hipótese de tratar-se de uma importante virada em sua percepção musical é a morte de Richard Wagner em Veneza, ocorrida ao mesmo tempo em que a parte final de Zaratustra era trazida à luz, completando uma gestação de dezoito meses.

${ }^{38}$ Ibidem, p. 86.

${ }^{39}$ Ibidem, p. 87.

${ }^{40}$ Sobre as ressonâncias nietzschianas na vida e obra de Thomas Mann, ver MANN, T. Nietzsches Philosophie im Lichte unserer Erfahrung: Vortrag AM XIV. Kongress des PEN-Clubs in Zürich am 3. Juni 1947. Basel: Schwabe, 2005; SCHMIDT, C. Ehrfurcht und Erbarmen: Thomas Manns Nietzsche-Rezeption 1914-1947. Trier: Wissenschaftlicher Verlag, 1997; PÜTZ, H. P. Kunst und Künstlerexistenz bei Nietzsche und Thomas Mann. Zum Problem des ästhetischen Perspektivismus in der Moderne. Bonn: Bouvier, 1997; GRÜNDLER, J-P. Friedrich Nietzsche in Thomas Manns Roman Doktor Faustus. Munique: Grin, 2003.

${ }^{41}$ A esse respeito, ver a famosa carta escrita na Califórnia e datada de 30/12/1945, em que Mann se reporta a Adorno para explicar a adoção da montagem como princípio construtivo em seu novo romance. ADORNO, T.; MANN, T. Briefwechsel: 1943-1955. Frankfurt a.M.: Suhrkamp, 2002. Edição inglesa: Correspondence: 1943-1955. Cambridge: Polity Press, 2006.

${ }^{42}$ MANN, T. Die Entstehung des Doktor Faustus. In: GW XI, p. 72. Edição brasileira: . A gênese do Doutor Fausto. São Paulo: Mandarim, 2001.

${ }^{43}$ Ver SILVA, E. S. N. "Os escritos musicais de Adorno: uma constelação em esboço". In: DUARTE, R.E; SAFATLE, V. (orgs.). Ensaios sobre música e filosofia. São Paulo: Humanitas, 2007, pp. 313332.

44 Tanto que, ao fim do livro, o autor publica uma nota de esclarecimento, onde adverte: "Não me parece supérfluo avisar o leitor de que o gênero de composição musical descrito no capítulo XXII e 
conhecido sob a denominação de técnica dodecafônica ou serial é propriedade intelectual de um compositor e teórico contemporâneo, Arnold Schönberg. Associei esta técnica, em certo contexto ideacional, ao vulto puramente fictício do músico, que é protagonista trágico do meu romance. De resto, devem as passagens do livro que tratam de teoria musical certos detalhes à Harmonielehre de Schönberg". MANN, T. Doutor Fausto, op. cit., p.710.

45 Ibidem, p. 87.

46 "Nunca há um documento da cultura que não seja, ao mesmo tempo, um documento da barbárie". BENJAMIN, W. apud LÖWY, M. Walter Benjamin: aviso de incêndio - Uma leitura das teses "Sobre o coneito de história". Tradução das teses de Jeanne Marie Gagnebin e Marcos Lutz Müller. São Paulo: Boitempo, 2005, p. 70.

${ }^{47}$ ADORNO, T. e HORKHEIMER, M. Dialética do esclarecimento: fragmentos filosóficos. Tradução de Guido Antônio de Almeida. Rio de Janeiro: Jorge Zahar., 1985, pp. 12-16.

${ }^{48}$ MANN, T. Doutor Fausto, op. cit., p. 342.

${ }^{49}$ Citando o prefácio epistemológico-crítico do livro do barroco de Walter Benjamin, Adorno sustenta em relação à música moderna: "A história filosófica como ciência da origem é a forma que, a partir dos extremos opostos, dos excessos aparentes da evolução, dá nascimento à configuração da ideia, entendida como uma totalidade caracterizada pela possibilidade de uma coexistência plena de sentido de tais contrários". BENJAMIN, W. apud ADORNO, T. Filosofia da nova música. São Paulo: Perspectiva, 2009, p. 13.

${ }^{50}$ Com o esgotamento do sistema tonal no início do século XX, os compositores põem-se a buscar maneiras alternativas de organização das notas musicais - posteriormente denominadas "atonalismo" - que não fossem exclusivamente baseadas na polarização de um eixo harmônico central. Schoenberg chegou a compor assim algumas peças musicais, mas logo considerou o atonalismo demasiadamente sem regras. Construiu, então, um método para organizar os doze tons da escala cromática igualmente. Essa técnica foi apresentada como "sistema dos 12 tons", que mais tarde se tornaria conhecida como dodecafonismo serial. Ver SAFATLE, V. "O novo tonalismo e o esgotamento da forma crítica como valor estético". In: DUARTE, R. e SAFATLE, V. (orgs.). Ensaios sobre música e filosofia, op. cit., pp. 75-101.

${ }^{51}$ ADORNO, T. Filosofia da nova música, op. cit., pp. 10-11.

${ }^{52}$ A esse respeito ver ADORNO, T. et al. Aesthetics and Politics. Londres; Nova lorque: Verso, 2007.

${ }^{53}$ ADORNO, T. Filosofia da nova música, op. cit., p. 104.

${ }^{54}$ Ibidem, p. 106.

${ }^{55}$ MANN, T. Doutor Fausto, op. cit., p. 338

${ }^{56}$ Ibidem, p. 339.

${ }^{57}$ ADORNO, T. Filosofia da nova música, op. cit, p. 107.

${ }^{58}$ MANN, T. Doutor Fausto, op. cit., p. 351.

${ }^{59}$ Ibidem, p. 350.

${ }^{60}$ Tomada de amores pelo príncipe, ela resolve fazer um pacto com uma terrível bruxa para tornarse humana, e assim tentar conquistar seu grande amor. O preço para isso, contudo, revela-se demasiado alto no final: além de sentir dores excruciantes, a Pequena Sereia deve abrir mão, não apenas da convivência com seus entes queridos, como ainda de sua voz magnífica e, sobretudo, de sua alma imortal. Ver ANDERSEN, H. C. "A Pequena Sereia". In: Contos de Andersen. Rio de Janeiro: Paz e Terra, 1988, pp. 83-107.

61 "O quadro sonoro de Leverkühn tem muito do poema de Dante e ainda mais daquele muro superpovoado, abarrotado de corpos, onde os anjos embocam os trompetes do Fim, o barco de 
Caronte despeja sua carga, os mortos ressuscitam, os santos adoram, máscaras diabólicas guardam o sinal do Minos cingido de serpentes, e o obeso condenado, abraçado, carregado, arrastado pelos sardônicos filhos do abismo, faz sua horrorosa jornada, cobrindo um dos olhos com a mão, ao passo que fixa, apavorado, o outro na catástrofe interminável, enquanto, a pouca distância dele, a Graça salva ainda da queda duas almas pecaminosas e as leva à Redenção. Em suma, falo dos grupos e dos acontecimentos reunidos no Juízo Final”. MANN, T. Doutor Fausto, op. cit., p. 501.

62 "Assim diz o Senhor Deus: Mal após mal, eis que vêm. Haverá fim, vem o fim, despertou-se contra ti; vem a tua sentença, ó habitante da terra. Vem o tempo; é chegado o dia da turbação, e não da alegria, sobre os montes. Em breve derramarei o meu furor sobre ti, cumprirei a minha ira, julgar-te-ei segundo os teus caminhos, e porei sobre ti todas as tuas abominações. Os meus olhos não te pouparão, nem terei piedade; segundo os teus caminhos, assim te castigarei". Ezequiel, 7.5-9.

${ }^{63}$ MANN, T. Doutor Fausto, op. cit., p. 501.

${ }^{64}$ Ibidem, p. 505.

${ }^{65}$ Ibidem, p. 245.

${ }^{66}$ Ibidem, p. 423.

67 Literalmente, aurora ou crepúsculo da humanidade. Ver PINTHUS, K. (org.). Menschheitsdämmerung: ein Dokument des Expressionismus. Berlim: Rowohlt, 2009.

${ }^{68}$ MANN, T. Doutor Fausto, op. cit., p. 629.

${ }^{69}$ SAFRANSKI, R. Romantismo: uma questão alemã. São Paulo: Estação Liberdade, 2010, pp. 335-356.

${ }^{70}$ Ver LÖWY, M. e SAYRE, R. "Figuras do romantismo anticapitalista". In: Romantismo e política. São Paulo: Paz e Terra, 1993.

${ }^{71}$ MANN, T. Doutor Fausto, op. cit., p. 709. 